\title{
SZAKTUDOMÁNYI, SZAKTÁRGYI ÉS SZAKMÓDSZERTANI TUDÁS MINT PEDAGÓGUS KOMPETENCIA MEGÍTÉLÉSE A PEDAGÓGUSOK KÖRÉBEN VÉGZETT KUTATÁS ALAPJÁN KAKNINCS-KISS BARBARA* - ÜTŐNÉ VISI JUDIT**
}

* az Eszterházy Károly Egyetem tanársegéde kissbarbara84@gmail.com

** Nemzeti Szakképzési és Felnőttképzési Hivatal szakmai vezetője judit.uto.visi@gmail.com

\begin{abstract}
A tanári pályára lépés és az azon való elörehaladás feltételeit jelentik azok a tanári kompetenciák, amelyek a pedagógusképzés tartalmi és szemléleti átalakitásával, illetve a tanári életpálya bevezetésével váltak széles körben ismertté. Ezek közé a kompetenciák közé tartozik a szaktudományi, szaktárgyi és szakmódszertani tudás. Tanulmányunk a TÁMOP 4.1.2.B.2-13/1 projekt keretében végzett interjúkon alapuló kutatás eredményeit mutatja be, és arra keresi a választ, hogy hogyan vélekednek a tanárok erröl a kompetenciáról, milyennek itélik meg a saját kompetenciájuk szintjét, illetve mit tesznek annak javítása érdekében. A válaszok alapján megállapítható, hogy a kompetenciát egyértelmüen fontosnak tartják. Általában elégedettek ilyen jellegü tudásukkal, de érzik a folyamatos fejlödés szükségességét, amelynek oka a társadalmi környezet, az iskolába bekerülö gyerekek ismereteinek, szokásainak és szocializációjának változása, illetve mind nagyobb különbsége.
\end{abstract}

\section{Bevezetés}

A tanári pályára lépés és az azon való előrehaladás feltételeit jelentik azok a tanári kompetenciák, amelyek a pedagógusképzés tartalmi és szemléleti átalakításával, illetve a tanári életpálya bevezetésével váltak széles körben ismertté. Az elmúlt időszakban egyre fontosabb kérdéssé vált, hogy mit gondolnak maguk a pedagógusok ezekről az elvárásokról, milyen mértékben tudnak azonosulni azokkal, illetve mennyire érzik úgy, hogy birtokában vannak az egyes pedagógus kompetenciáknak.

Az általunk vizsgált kompetencia a tanár által tanított tantárgyakhoz kapcsolódó biztos szakmai tudás meglétén túl felételezi az ismeretek hatékony, a tantervi elvárásokkal összhangban történő átadásához szükséges tantárgypedagógiai, tanulásszervezési képességek meglétét. A kompetencia-leírás megfogalmazza azt is, hogy a tanár törekszik szaktudományi, szaktárgyi, tanuláselméleti és tantervi tudásának bővítésére illetve minél hatékonyabb integrálására, a képességek és a 
tudásrendszerek fejlesztésének egységben való kezelésére annak érdekében, hogy a tantárgyban rejlő személyiségfejlesztési lehetőségeket megvalósítsa ${ }^{1}$.

A kompetencia általános megfogalmazásán túl a tanári előmenetelhez kapcsolódó leírásokban a kompetencia tartalma három összetevő köré csoportosul: 1. szakmódszertani tudás, 2. szaktárgyi tudás, szaktárgyi integráció, IKT kompetenciák, 3. szakmai tudatosság.

Tanulmányunk a TÁMOP 4.1.2.B.2-13/1 projekt keretében végzett interjúkon alapuló kutatás eredményeit mutatja be, és arra keresi a választ, hogy hogyan vélekednek a tanárok a szaktudományi, szaktárgyi és szakmódszertani tudásukról, illetve az ehhez kapcsolódó kompetenciákról.

\section{Az interjú kérdései}

A szaktudományi, szaktárgyi, szakmódszertani tudás kompetenciáról a bevezetőben leírt szempontok alapján fogalmaztuk meg azt a kérdéssort, amellyel az interjúalanynak a szakmai, módszertani tudással kapcsolatos ismereteit, nézeteit igyekeztünk feltárni. Szerettünk volna képet kapni arról is, hogy milyennek ítéli meg a válaszoló saját kompetenciájának szintjét, illetve mit tesz annak javítása vagy szinten tartása érdekében. A kérdésekre adott válaszok közvetve tükrözik a válaszadónak a témával kapcsolatos attitüdjét is.

A kérdések nem térnek ki az adott kompetencia minden részelemére, de a legfontosabb szempontokra igen. Érintik a kompetencia szakmódszertani tudás aspektusát (1., 2. kérdés), a szakmai tudatosságot, a szaktárgyi tudást és integrációt - tudás és attitüd szempontból (3., 4. és 6. kérdés), a szakmai tudatosságot, a szaktárgyi tudást és integrációt attitüd szempontból (5., 7. kérdés).

Az interjú kérdéssora:

- Szaktárgyi tudását megfelelőnek ítéli? Ha szükséges, hol, milyen módon pótolja hiányosságait?

- Melyek azok a területek, ahol úgy érzi, módszertani tudását gyarapítania kellene?

- Véleménye szerint milyen kiemelt szerepe van szaktárgya tanulásának a tanulók személyiségfejlesztésében?

- Véleménye szerint tanítványai össze tudják kapcsolni az ön tárgyában tanultakat más tantárgyak tananyagaival?

- Hogyan használja ki az iskolán kívüli tanítási-tanulási lehetőségeket a tantárgya tanítása során?

1 https://pedtanar.files.wordpress.com/2014/09/reszletes_kompetenciak_elte_20060205.pdf Letöltés ideje: 2017. február 10. 
- Milyen gyakorisággal olvas szakmai-szakmódszertani folyóiratokat (nyomtatott vagy on-line)? Milyen mértékben tartja ezeket hasznosíthatónak saját tantárgya oktatásában?

- Véleménye szerint reálisak-e, megvalósíthatók-e a tantervi, kerettantervi követelmények? Véleményét indokolja!

\section{A kérdésekre adott válaszok}

\section{A szaktárgyi tudás megitélése}

A válaszok alapján megállapítható, hogy a megkérdezettek döntő többsége elégetett szakmai tudásával és megfelelőnek tartja azt. A megkérdezettek közül 52-en teljes mértékben elégedettek, 4 fö nyilatkozott úgy, hogy csak részben, és ugyancsak 4-en mondták azt, hogy nem elégedettek azzal. A részben elégedettek, illetve az elégedetlenek esetében nem mutatható ki szoros összefüggés az iskolatípus, az életkor vagy az oktatott szakok alapján. Azt elmondhatjuk, hogy a rövidebb ideje (14 évnél kevesebb) a pedagógus pályán lévők között csak 1 fö volt elégedetlen a szakmai tudásával, míg a többiek teljes mérték. De meg kell jegyeznünk azt is, hogy az ebbe a csoportba tartozó megkérdezettek létszáma is alacsony volt. Nincs lényeges különbség a nemek között sem. A férfi kollégák 1\%-a, a nőknek pedig a 0,7\%-a volt részben vagy teljesen elégetlen saját szakmai tudásával. A szakmai elégettség még abban az esetben is szinte teljes mértékü volt, ha olyan tárgyat tanított a válaszoló, amelyre nem volt szakképesítése. Az egyéb pedagógiai feladatok ellátásához kapcsolódóan két terület rajzolódott ki. A szakkörök és a közösségi szolgálatot koordináló pedagógusok között voltak a legtöbben, akik nem érezték eléggé biztosnak a szakmai tudásukat. Itt vélhetően a speciális szakmai tudás hiánya jelentette a problémát.

Kíváncsiak voltunk arra is, hogy milyen forrásból, illetve milyen módon pótolják az esteleges szakmai hiányaikat a kollégák. Egy olyan kolléga akadt, aki úgy érezte, hogy egyáltalán nincs szüksége erre. Az ismeretek pótlására, illetve szinten tartására a legnépszerübb módszer a szakmai kiadványok fellapozása, az internet segítségével történő tudásszerzés és a tanfolyamok. Ez minden korosztályban és iskolatípusban jellemző. Kissé talán meglepő, hogy még az idősebb kollégák közül is nagyon sokan jelölték meg az internetet a legfontosabb eszköznek. Érdekes, hogy a kollégákkal való megbeszélést általában nem tartják fontos módszernek a megkérdezettek, ez alól csak a közösségi gyakorlatot koordináló kollégák jelentenek kivételt. Külön ki kell emelni, hogy többen fontosnak tartották az idegen nyelvü könyvek, filmek felhasználását is. 


\section{A módszertani tudás gyarapitása}

Megkérdeztük, hogy melyek azok a területek, ahol úgy érzi, módszertani tudását gyarapítania kellene. A válaszadáshoz elöre megadtunk olyan módszertani eszközöket, amelyek tanórai alkalmazásáról sokszor esik szó napjainkban. A válaszok megoszlását az 1. ábra szemlélteti.

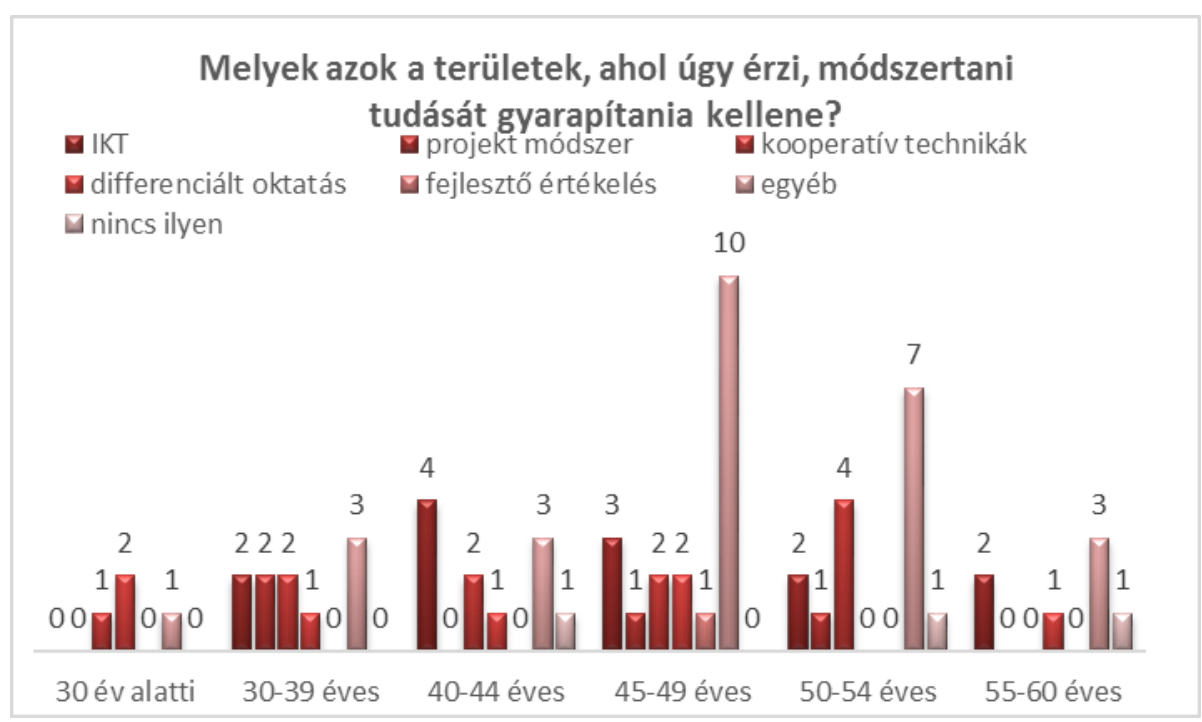

1. ábra: Fejlesztésre szoruló módszertani tudásterültek a pedagógusok életkora szerinti bontásban

Megállapítható, hogy olyan kolléga, akinek egyáltalán nem volt szüksége fejlesztésre mindössze 1 fö volt. A legfiatalabb korcsoporton kívül mindenhol hangsúlyosan jelenik meg az IKT gyarapítása iránti igény. A projektmódszer és a kooperatív technikák iránti érdeklődés már nagyobbak az eltérések. Meglepő ugyanakkor, hogy a differenciált oktatást és a fejlesztő értékelés alkalmazását segítő kurzusok iránt alig fogalmazódott meg igény. Nem tudjuk eldönteni, hogy a kollégák még napjainkban sem ismerték fel ezek fontosságát vagy az eddigi továbbképzéseken már megvalósult az ilyen irányú fejlesztés. Magas az egyéb területek említése. Ez azt jelenti, hogy a megkérdezettek nem az általunk kiemelt módszertani eszközök alkalmazása terén éreznek hiányosságokat, hanem más terülteken várnak segítséget. A válaszok alapján ilyenek: a fejlesztő pedagógia, az SNI-s, BTM-s tanulókkal való foglalkozás, a megfelelő pedagógiai-pszichológiai ismeretek, a tanulásszervezés és a tanügyi dokumentációk készítésének támogatása. Bár a kollégák úgy nyilatkoztak, hogy alapvetően jónak ítélik meg saját szaktárgyi és módszertani tudásukat, szerettük volna ezt a témát más oldalról is megvizsgálni. 
A módszertani-szakmai tudás megítélésére következtethetünk abból is, ahogy a kollégák a szakmai-módszertani folyóiratok iránti érdeklődésükről nyilatkoznak. Ehhez kapcsolódóan két kérdést tettünk fel: milyen gyakran olvasnak ilyen folyóiratokat (nyomtatott vagy on-line formában), és milyen mértékben tudják az olvasottakat hasznosítani a tantárgyuk oktatásában.

A megkérdezettek több mint fele (54\%-a) nyilatkozott úgy, hogy heti rendszerességgel olvas szakfolyóiratot. A válaszolók $24 \%$-a havonta, 19\% pedig ritkábban, csak szükség esetén lapozza fel a folyóiratokat. Két válaszadó volt, aki eltérő okból ugyan, de nem olvas szakmai lapokat.

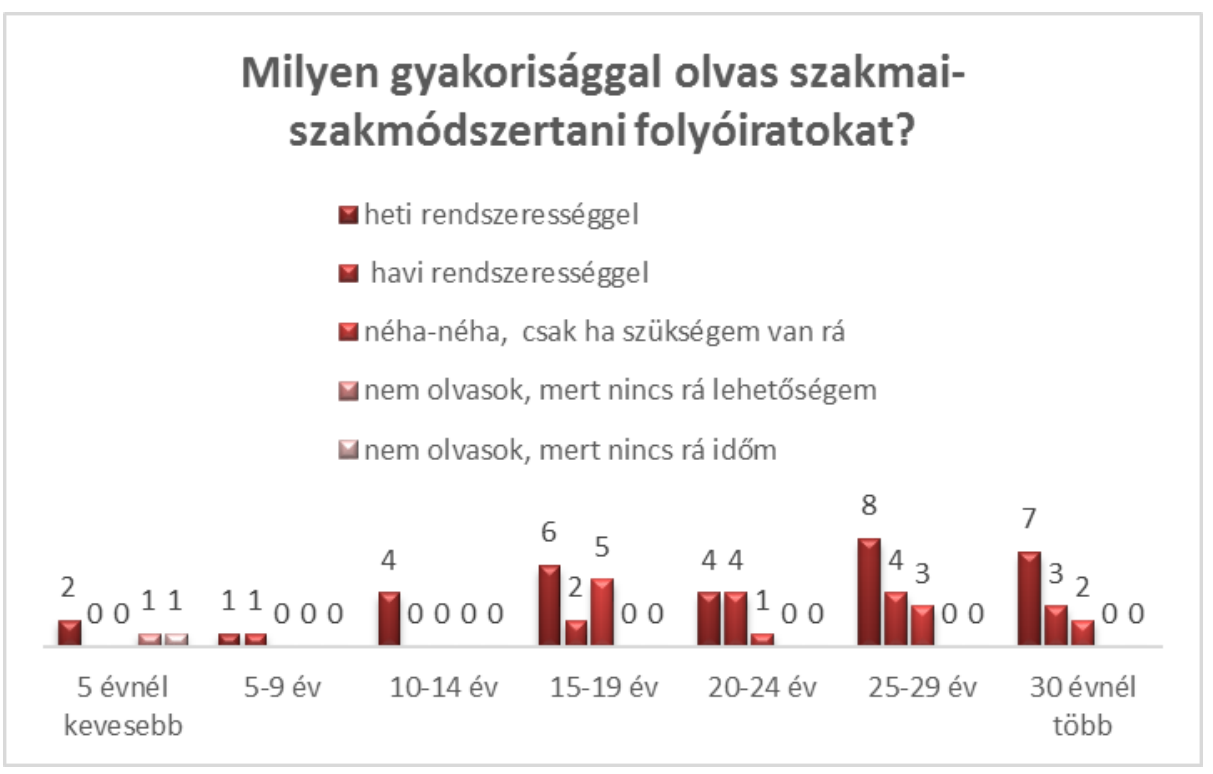

2. ábra: A szakfolyóiratok iránti érdeklődés és a pályán eltöltött idő összefüggései

Némileg árnyalódik a kép, ha a válaszokat a pályán eltöltött idő függvényében vizsgáljuk meg. A pályán 25 évnél régebb óta tevékenykedők esetében egyértelmüen többségben vannak a szakmai anyagokat gyakran és rendszerességgel olvasók. Az a két válaszadó, aki egyáltalán nem olvas szakfolyóiratot pedig a kezdők közül került ki (2. ábra). A minta alacsony száma miatt természetesen itt sem tudunk egyértelmú megállapításokat megfogalmazni.

Megállapítható az is, hogy arányaiban az általános iskolai tanárok a legérdeklődőbbek, 64 \%-uk heti rendszerességgel olvas szakirodalmat. Ez a tanítók és a középiskolai tanárok esetében $50-50 \%$.

Az önmagában még nem felétlenül jelenti a szakmai-módszertani megújulás iránti hajlandóságot, ha pusztán elolvassuk a szakfolyóiratokat. Többet árul el erröl, ha azt vizsgáljuk meg, hogy milyen mértékben tartjuk alkalmazhatónak ezeket az 
információkat saját tanári munkánk során. A válaszolók 76\%-a tartotta hasznosíthatónak, a konkrét oktató-nevelő munkába történő beépítésére alkalmasnak a szakfolyóiratokban olvasottakat. Arra, azonban, hogy az alkalmazás ténylegesen megvalósul-e, sajnos most nem tudtunk rákérdezni.

A pályán eltöltött idő alapvetően nem befolyásolja a szakfolyóiratokban leírtakkal kapcsolatos vélekedést. Árnyaltabbá válik ugyanakkor a kép, ha a tanárok szakképzettségével vetjük össze a felhasználási hajlandóságot (3. ábra). Megállapítható, hogy az általános iskolai tanárok tartják leginkább hasznosíthatónak a szakmai újdonságokat. Az ő esetükben ez a megkérdezettek 91\%-át jelenti. A tanítók esetében ez 70\%, míg a középiskolai tanárok között már csak $62 \%$. Ez az arány egybeesik azzal a tapasztalattal, hogy a szakmódszertani jellegű szakmai továbbképzéseken legnagyobb számban az általános iskolai tanárok vesznek részt, legkevésbé pedig a középiskolában tanítók kapcsolódnak be ezekbe a képzésekbe.

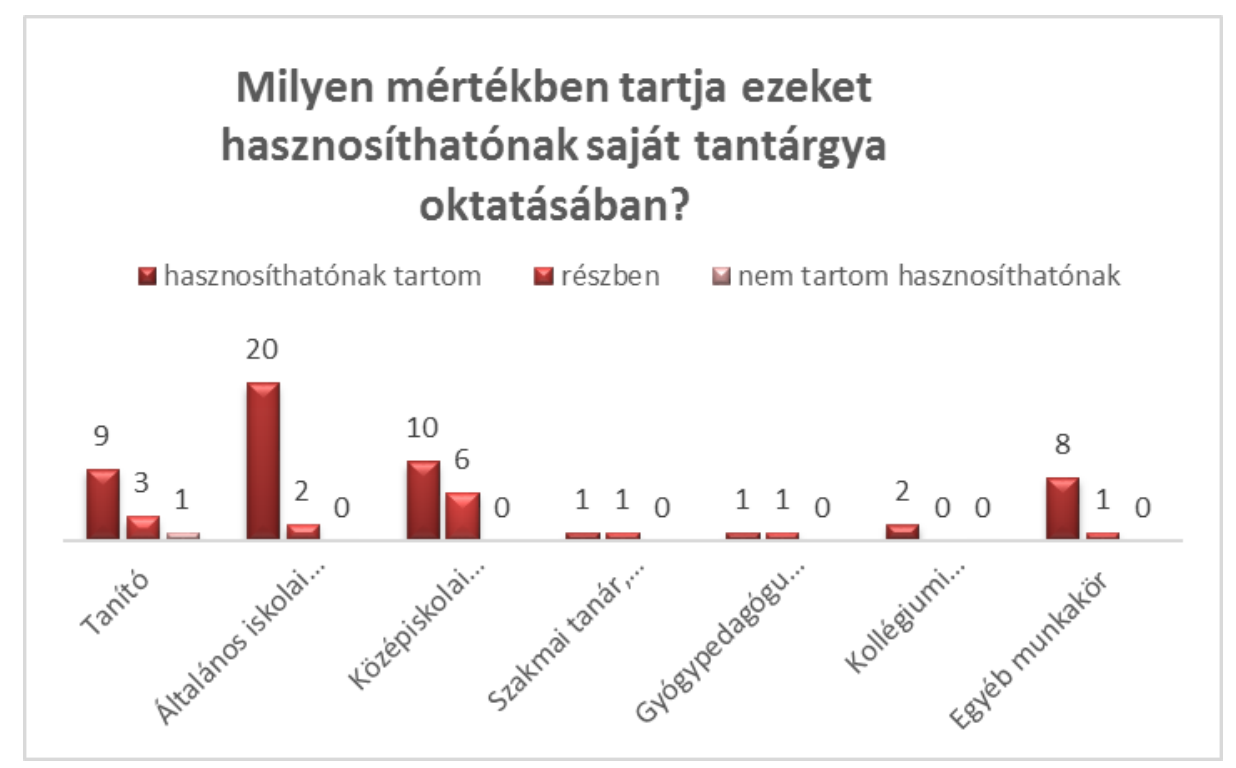

3. ábra: Az olvasottak hasznosíthatóságának megítélése tanári képzettség szerint

\section{A tanitott szaktárgy szerepének megitélése}

A szakmai-módszertani kultúrával kapcsolatos vélemények feltárása után olyan kérdések következtek, amelyek a tanított szaktárgy szerepének megítélésére vonatkoztak. Ezek a kérdések a szakmai tudatosságról szerettek volna információt gyüjteni. Az első ezek közül a tanított szaktárgy tanulók személyiségfejlesztésében betöltött szerepének megítélését vizsgálta. 
A válaszadáshoz ebben az esetben is adtunk meg szempontokat, olyanokat, amelyet a NAT közös fejlesztési céljai, feladatai alapján fogalmaztunk meg: nemzeti öntudat kialakítása, hazaszeretet, európaiság, környezeti szemlélet, tolerancia. (A válaszadók több területet is megjelölhettek.) Természetesen ebben a kérdésben a válaszadást alapvetően befolyásolta a riportalany szakja. A válaszok alapján megállapítható, hogy a felkínált célokat kevesen választották, a legtöbben egyéb fejlesztő szerepet tulajdonítottak saját tantárgyuk oktatásának. Érdekes, hogy a nemzeti öntudat említése egyik tárgyban sem jelenik meg, de alig kap hangsúlyt a haza iránti kötődés kialakítása is. Az is meglepő, hogy a természettudományos tárgyat tanítók is elsiklottak a környezeti szemlélet fejlesztése felett. Az egyéb fejlesztési szerepek között az alábbiakat sorolták fel: kommunikáció, önkifejezés, olvasóvá nevelés, kötelességtudat, realitásérzék, más kultúrák tisztelete, érzelmi, esztétikai nevelés, empátia, nyitottság, kritikus, kreatív gondolkodás, szociális képességek, egészséges életmód. Az azonban mindenképpen pozitív, hogy azt, hogy az adott szaktárgynak nincs személyiségfejlesztő szerepe senki nem válaszolta.

Egy másik kérdésben ugyancsak a szaktárgy szerepének megítélésével kapcsolatban a tantárgyi integráció lehetőségeinek megítélésére voltunk kíváncsiak, amikor arra kérdeztünk rá, hogy véleménye szerint tanítványai össze tudják-e kapcsolni az ön tárgyában tanultakat más tantárgyak tananyagaival.

Általánosságban megállapítható, hogy a tanárok döntő többsége úgy gondolja, a diákok össze tudják kapcsolni a különbözö tantárgyakban tanultakat. A válaszokat részletesebben megvizsgálva azonban néhány érdekes megítélésbeli különbség derült ki. A gimnáziumi tanárok körében magasabb azok aránya, akik csak részben értenek egyet azzal, hogy a tanulók fel tudják használni az általuk tanítottakat már tantárgyakban, mint az általános iskolában tanítók között. A tanított szakok alapján a legpesszimistábbak a történelemtanárok, itt egyenlö arányban vannak azok, akik igennel és azok, akik nemmel, illetve „részben”-nel válaszoltak erre a kérdésre. Hasonlóan vélekedek a történelemmel rokon jelenismeretet, filozófiát tanítók, illetve a szakmai tárgyakat oktató kollégák is. Ugyanakkor a magyar- és az idegen nyelv tanárok közül valamennyien úgy vélték, hogy a tárgyaikban tanultak más tantárgyak tanulása során is hasznosíthatók. A korcsoportok alapján a fiatalabb kollégák bíznak jobban a tantárgyak közötti kapcsolatban, míg az idősebbek (50 éven felüliek) és a régebb óta a pályán lévők (30 évnél több) kevésbé gondolják úgy, hogy a tantárgyukban tanultakat a tanulók máshol is hasznosíthatják.

Bizonyos szempontból a tantárgy presztízsére (adhatók-e ilyen feladatok, motiváltak-e ezek teljesítésében a tanulók), illetve a tanulás támogatására is következtethetünk azokból a válaszokból, amelyek arra a kérdésre érkeztek, hogy hogyan használják ki a kollégák az iskolán kívüli tanítási-tanulási lehetőségeket a tantárgyuk tanítása során.

A megkérdezettek döntő többsége, közel 70\%-a, azt válaszolta, hogy részben használja csak ki az iskolán kívüli tanítási-tanulási lehetőségeket, 27\%-uk teljes 
mértékben, 3\% pedig egyáltalán nem él ezzel. Olyan nem volt a megkérdezettek között, aki szívesen kihasználná, de nincs erre lehetősége.

A tanórán kívüli tevékenységekben valamivel aktívabbaknak tünnek a fiatalabb korosztályba tartozó, pályakezdő kollégák. Ennek oka kereshető a tanárképzés megújulásában, az új tanulás-tanításszervezési módszerek ismeretében, de a fiatalabb életkorból adódó rugalmasabb időbeosztásban, aktivitásban is. A minta kis száma miatt azonban mélyebb következtetések nem vonhatók le az adatokból.

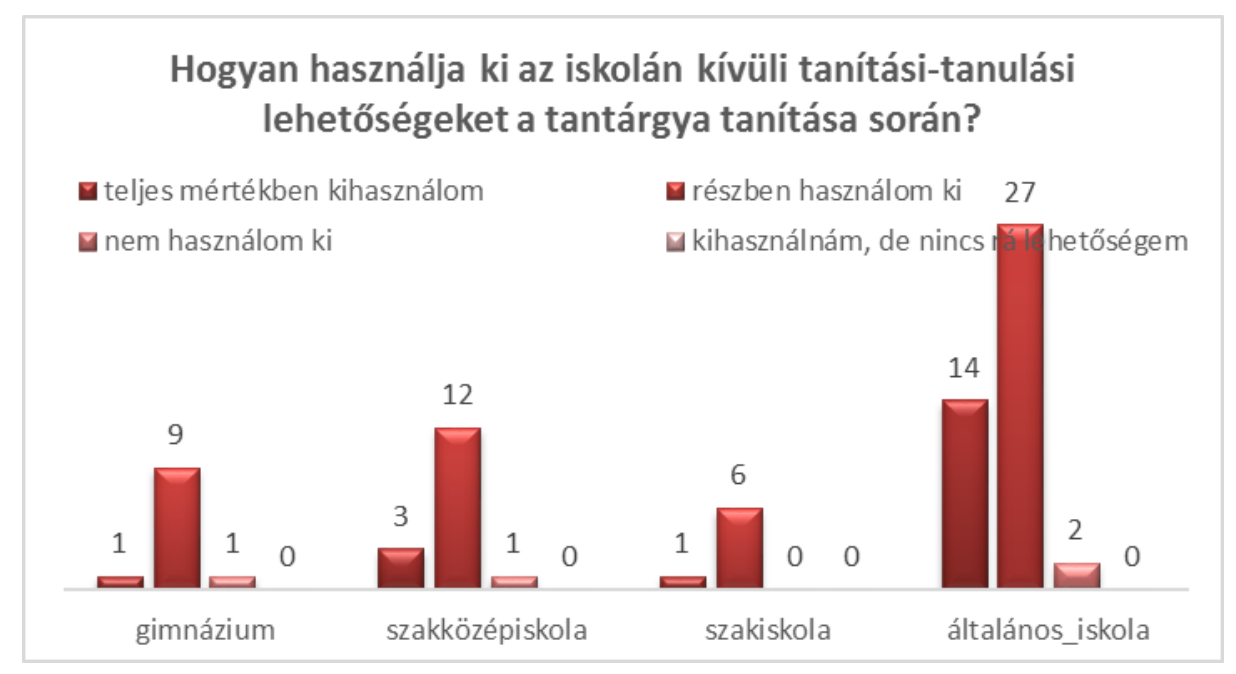

4. ábra: A tanórán kívüli lehetőségek kihasználásának megoszlása iskolatípusok szerint.

Ha összevetjük az egyes iskolatípusokban tanítók válaszait, már lényeges eltérést találunk (4. ábra). Az általános iskolában tanítók közül jóval többen - a megkérdezettek 32\%-a - használja ki teljes mértékben a tanórán kívüli lehetőségeket. Ezzel szemben a gimnáziumokban és a szakiskolában szinte alig van ilyen. Ennek oka lehet természetesen az egyes iskolatípusokban kialakult hagyományosan eltérő időbeosztás, az általános iskolára jellemző napközi, illetve az egész napos iskola nyújtotta lehetőségek kihasználása. Megjegyzendő ugyanakkor, hogy az általános iskolákban nagyobb hagyománya is van a közös, iskolán kívüli programoknak (szakkörök, erdei iskola, táborok stb.).

Különbség figyelhető meg a válaszok között az intézmények telephelye szempontjából is. Megállapítható, hogy a városi, illetve a megyeszékhelyen lévő iskolák esetében magasabb a teljes mértékben kihasználom válaszok aránya. A városi iskolában tanítók 35\%-a, megyeszékhelyen tanítók $20 \%$, a falun dolgozóknak már csak 14\%-a nyilatkozott úgy, hogy teljes mértékben él a lehetőségekkel. 
Érdemes kitérni arra is, hogy milyen eltérések figyelhetők meg a különböző szaktárgyakat oktató kollégák között. A legnagyobb mértékben a magyart és a müvészeti tárgyakat tanítók használják ki a tanórán kívüli lehetőségeket. Ezekben a tárgyakban azok vannak többségben, akik úgy nyilatkoztak, hogy teljes mértékben élnek ezzel. Ez tulajdonképpen nem is meglepő, hiszen a hazai oktatásban eddig is nagy hagyományai voltak a közös színház vagy kiállítás látogatásnak, és ezt követően az élmények tanórai feldolgozásának. Az azonban elgondolkoztató, hogy a megkérdezett természettudományos tárgyat tanító kollégák között nem volt olyan, aki teljes mértékben élt volna a tanórán kívüli lehetőségekkel. A minta kis száma miatt természetesen nem lehet messzemenő következtetéseket levonni a válaszokból, és kevés az okokat mélyebben feltáró háttéradat is, mégis felvetődik a gondolat, hogy a természettudományos tárgyak oktatásának problémája nem vezethető-e vissza arra is, hogy a tanárok sem élnek igazán a tanulók érdeklődését felkeltő, a természeti-környezeti folyamatokat a valóságban bemutató lehetőségek kihasználásával. (terepgyakorlat, terepi munka, otthoni megfigyelés stb.).

\section{A szakmai elvárások realitásának megitélése}

A szaktárgyi tudáshoz kapcsolódóan feltett utolsó kérdéskör a szaktárgyukkal kapcsolatos tantervi követelmények megítélésére vonatkozott. Arra voltunk kíváncsiak, hogy a kollégák a saját tantárgyuk szempontjából mennyire tartják reálisnak a követelményeket. Arra is kértük őket, hogy indokolják meg véleményüket.

A kérdésre csak kevesen, mindösszesen csak 28 -an válaszoltak. A vélemények ebben a kérdésben eléggé megoszlottak. A tanárok 42\%-a szerint teljesíthetők, $58 \%$ szerint viszont nem. Ha részletesebben is elemezzük a válaszokat, megállapítható, hogy az idősebbek és a régebb óta a pályán lévők voltak valamivel elfogadóbbak, ő közülük tartják többen teljesíthetőnek az elvárásokat. Lehetséges, hogy ebben szerepe van a nagyobb szakmai rutinnak, és annak, hogy pályafutásuk során már többször kellett megfelelniük hasonló kihívásoknak. 


\section{Véleménye szerint reálisak-e, megvalósíthatók-e a tantervi, kerettantervi követelmények?}

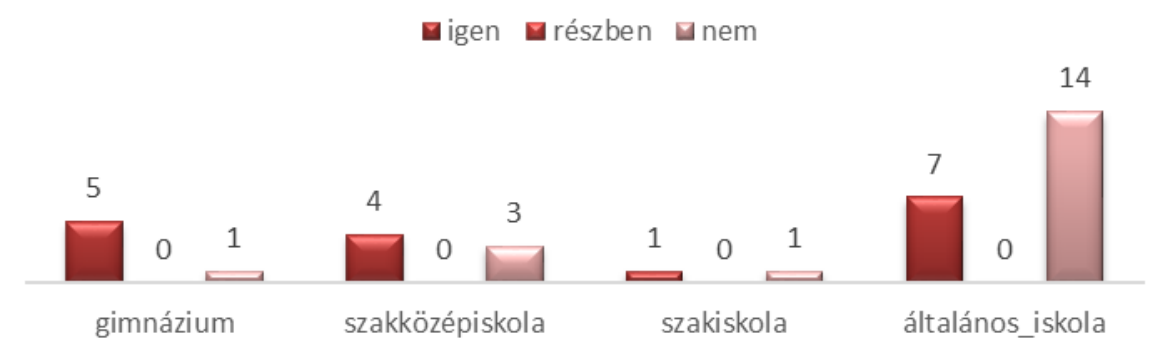

5. ábra: A megvalósíthatóság megítélése iskolatípusok szerint

Nagyobb a különbség a megítélésben, ha az iskolatípusok szerinti megoszlást nézzük. A gimnáziumban és a szakközépiskolában tanítók esetében többségben vannak azok, akik teljesíthetőnek tartják a követelményeket. Különösen igaz ez a gimnáziumban oktatókra esetében (5. ábra). Az általános iskolai tanárok közül ugyanakkor a megkérdezettek kétharmada gondolja úgy, hogy nem teljesíthetók az elvárások.

Tovább árnyalja a képet, ha külön vizsgáljuk az általános iskola alsó, illetve felső tagozatán tanítók véleményét. Így láthatóvá válik az is, hogy a felső tagozatos tanárok tartják leginkább túlzónak a központi elvárásokat. A tanítók - bár közöttük is többségben vannak a ,nem”-mel válaszolók - reálisabbnak érzik a követelményeket. Eltér a különböző tantárgyakat tanítók véleménye is. A matematika-informatika, a történelem és - az alacsony óraszámban, illetve csak kevés évfolyamon oktatott - filozófia, hittan-erkölcstan tárgyakat tanítók döntő többsége, az utóbbi tantárgycsoportban érintetteknek pedig a teljes köre gondolja úgy irreálisak az elvárások. A legelfogadóbbak - nem kis meglepetésre természettudományos tárgyakat oktatók és a magyar szakosok.

A természettudományos tárgyakat tanítók véleménye azért meglepő, mert a tantárgyak alacsony heti óraszáma, illetve csak néhány évfolyamra korlátozódott önálló előfordulása miatt a szaktanárok számos fórumon emelték fel hangjukat, és ezzel együtt hangsúlyozták a túlzott tantárgyi követelményeket. Különösen az általános iskola felső tagozatára készült kerettantervekkel szemben fogalmazódtak meg élesen ezek a kritikák.

Kértük a kollégákat arra is, hogy indokolják meg a véleményüket. Ehhez megadtuk a különböző szakmai fórumokon leginkább megfogalmazott észrevételeket, amelyek közül a válaszolók többet is megjelölhettek. A válaszadók 
40\%-a szerint kevés az idő, $26 \%$ a sok és nehéz tananyagra panaszkodott, $14 \%$ említette a hiányzó alapokat, $16 \%$ jelölt meg egyéb tényezőt, és mindössze 1 említést kapott a tanulói motiváció hiánya. Ez utóbbi kissé meglepő, mert erre a tényezőre egyébként sokszor hivatkoznak a kollégák.

A véleményeket némileg árnyalja a pályán eltöltött idő, de jelentős különbség nincs az egyes csoportok vélekedésében. Ahogy várható volt az időhiány minden iskolatípusban probléma, de leghangsúlyosabban az általános iskolában fogalmazódik meg (6.ábra).

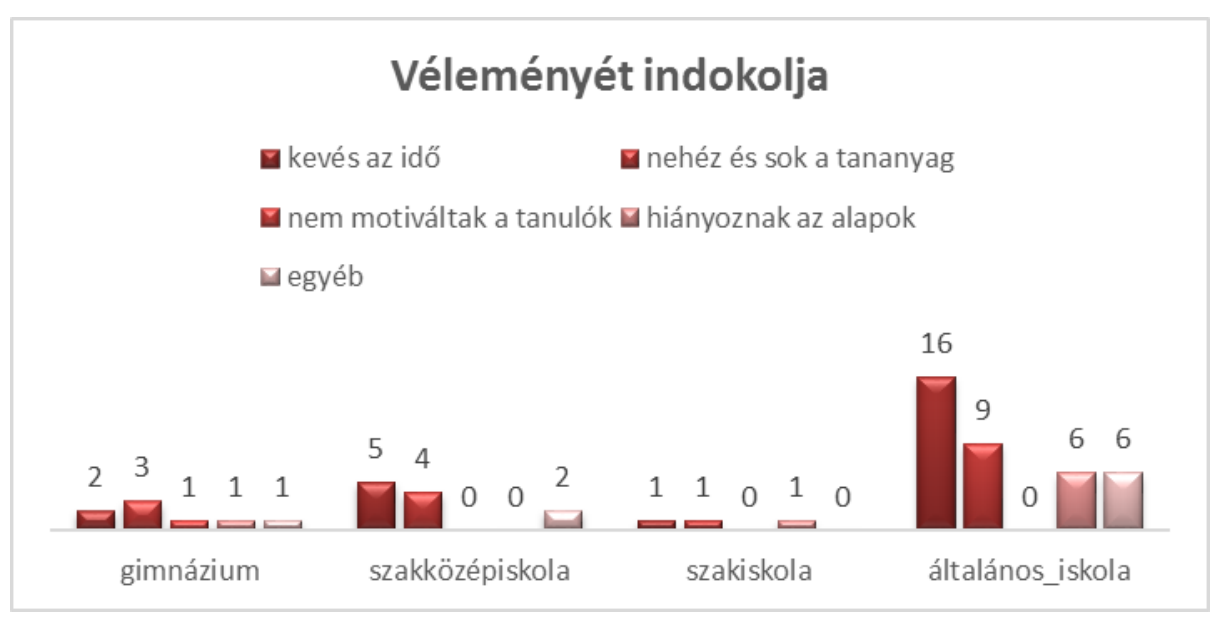

6. ábra: Az indokok megoszlása iskolatípus szerint

Megjegyzendő, hogy a nehéz és sok tananyag indok is bizonyos szempontból visszavezethető az időproblémára. Lehetséges, hogy nagyobb óraszámmal a jelenleg soknak és nehéznek tartott tananyag már teljesíthetö lenne.

Ha a szaktárgyak szempontjából nézzük a különbséget, akkor az időprobléma mindenhol megjelenik, de leghangsúlyosabb az idegen nyelv és a müvészeti tárgyat tanítók körében. Ez a müvészeti tantárgyakat tanító kollégák estében teljesen érthetö, ugyanakkor elgondolkoztató az amúgy is nagyon magas óraszámban tanító idegen nyelv szakosok esetében. A magyar nyelv és irodalom esetében nem annyira a sok tananyag, mint inkább a kevés idő okozza a problémát. A matematikát és a természettudományos tárgyakat tanítók mindkét szempontból nehézségeket látnak. A testnevelők körében pedig hangsúlyosan fogalmazódik meg az alapok hiánya, ami egyébként a szakmai tárgyak oktatását is megnehezíti. Az egyéb nehezítő tényezők között a témakörök nem megfelelő belső arányát, a szociokulturális különbségeket, az otthon meghatározó szerepét említették. Többen is utaltak arra, hogy a megvalósíthatóság erősen függ a tanulók képességeitől, a tanulói közösségektől. 


\section{Összegző gondolatok}

$\mathrm{Az}$ interjúban elhangzottak alapján megállapítható, hogy a kompetenciát egyértelmúen fontosnak tartják a pedagógusok. Elsősorban a szaktudományi és szaktárgyi tudás az, amelyet alapvető jelentőségünek éreznek a tanári munka szempontjából, bár sok esetben ezt nem választják élesen szét a szakmódszertani tudástól. A két fogalom sok válaszolónál keveredik. A megkérdezettek általában elégedettek ilyen jellegü tudásukkal, de érzik a folyamatos fejlődés szükségességét, amelynek oka a társadalmi környezet, az iskolába bekerülő gyerekek ismereteinek, szokásainak és szocializációjának változása, illetve mind nagyobb különbségei. Éppen ezek a társadalmi kihívások erősítik fel a tanárokban a szakmódszertani, illetve ezt megalapozó pedagógiai-pszichológiai ismeretek iránti érdeklődést. Ezt a riportok során is megtapasztalhattuk.

A kompetenciához kapcsolódó fejlődéshez részben tudatos önmüvelésre, részben pedig jól összeállított, az elméletet (szakmai ismeretek, alkalmazásuk pedagógiai-módszertani háttere) és tanórai gyakorlatot egyaránt felölelö továbbképzésekre lenne szükség. Ide tartozhatnak a jó gyakorlatokat bemutató szakmai workshopok, a szervezett tanóra-látogatások. Mindenképpen erősíteni kellene a pedagógusok közötti szakmai kommunikációt, kihasználva az egymástól való tanulás lehetőségét.

A szaktanárok korszerü szakmódszertani tudása lehet éppen az alapja annak is, hogy - a teljesíthetőség szempontjából igencsak eltérően megítélt - kerettantervek elvárásai végül mégis teljesíthetők legyenek. 